THE GREAT BASIN 



\title{
The Great Basin
}

\author{
A NATURAL PREHISTORY \\ REVISED AND EXPANDED EDITION
}

DONALD K. GRAYSON

甲

UNIVERSITY OF CALIFORNIA PRESS

Berkeley Los Angeles London 
University of California Press, one of the most distinguished university presses in the United States, enriches lives around the world by advancing scholarship in the humanities, social sciences, and natural sciences. Its activities are supported by the UC Press Foundation and by philanthropic contributions from individuals and institutions. For more information, visit www.ucpress.edu.

For a digital version of this book, see the press website.

University of California Press

Berkeley and Los Angeles, California

University of California Press, Ltd.

London, England

C 2011 by the Regents of the University of California
Library of Congress Cataloging-in-Publication Data

\section{Grayson, Donald K.}

The great basin : a natural prehistory / Donald K. Grayson. Rev. and expanded ed.

p. $\mathrm{cm}$.

Rev. ed. of: The desert's past. c1993.

Includes bibliographical references and index.

ISBN 978-0-520-26747-3 (hardback)

1. Geology, Stratigraphic-Pleistocene. 2. Geology,

Stratigraphic—Holocene. 3. Geology—Great Basin.

4. Paleontology—Great Basin. 5. Indians of North

America-Great Basin-Antiquities. 6. Paleo-Indians-Great

Basin. 7. Great Basin-Antiquities. I. Grayson, Donald K.

Desert's past. II. Title.

QE697.G8 2011

508.79—dc22

2010052100

The paper used in this publication meets the minimum requirements of ANSI/NISO Z39.48-1992 (R 1997)(Permanence of Paper).

Cover image: Black Rock Desert, Nevada. Photo by the author. 
For Barbara, who was my life 
